\title{
The Quiet Politics and Gentle Literary Activism Behind the Battle for Utah's Bears Ears National Monument
}

Accepted for publication in Area. The information, practices and views in this article are those of the author

and do not necessarily reflect the opinion of the Royal Geographical Society (with IBG).

\section{Author:}

Laura Smith

College of Life and Environmental Sciences, University of Exeter, Exeter, UK

Email: laura2.smith@exeter.ac.uk

Article type: Special Section [Gentle geographies in and beyond spaces of injustice and activism: taking

care in research and practice]

\begin{abstract}
In the closing weeks of his administration, President Obama used his authority under the 1906 Antiquities Act to designate the 1.35-million-acre Bears Ears National Monument in southern Utah, a redrock landscape sacred to many Native American tribes. With the designation, Bears Ears became the second national monument in Utah-after Grand Staircase-Escalante National Monument, designated in 1996-where literature and the literary imagination had formed part of the arsenal of campaigners petitioning for the designation. This discussion looks to the works of writers across the American West who have spoken out in defense of Bears Ears (both pre- and post-designation), to consider the place of literature in environmental activism. In particular, this discussion examines how literary activism emerges as a creative yet gently subversive performance, allowing commentators to speak back to an ethics of (ecological) care, responsibility, and to respond to injustices at Bears Ears. Across these two national monuments, and three accompanying and pivotal anthologies, this discussion unpacks and interrogates an ongoing gentle political rhetoric and dialogue surrounding the Bears Ears national monument. But this quiet resilience has been disrupted, upended by the Trump administration's review of more than two dozen national monument designations, which specifically targets Bears Ears, but also includes Grand StaircaseEscalante.
\end{abstract}

Acknowledgments: I would like to thank Matt Finn and Jayne Jeffries for putting together this Special

This article has been accepted for publication and undergone full peer review but has not been through the copyediting, typesetting, pagination and proofreading process, which may lead to differences between this version and the Version of Record. Please cite this article as doi: $\underline{10.1111 / \text { area. } 12609}$

This article is protected by copyright. All rights reserved 
Section, and the two anonymous reviewers for their valuable comments and suggestions.

Funding information: There are no funders to report for this submission

Data availability statement: Data sharing is not applicable to this article as no new data were created or analyzed in this study.

This article is protected by copyright. All rights reserved 
Article type : Special Section

\section{INTRODUCTION}

With just three and a half weeks remaining of his presidency, President Obama used his authority under the 1906 Antiquities Act to designate the 1.35-million-acre Bears Ears National Monument in southeastern Utah. But less than a year later, President Trump would sign twin proclamations modifying the boundaries of not only Bears Ears, but a second Utah national monument, Grand Staircase-Escalante. Throughout campaigns by Native Nations and conservation groups to secure designation of a Bears Ears national monument (and subsequent campaigns defending the designation against a new administration hostile to public lands protections), literature and the literary imaginary flourished as a platform for celebrating the redrock canyons, mesas, and spires of the sacred, ancestral Bears Ears country. This paper follows the genesis of this gentle literary activism and advocacy to explore how those who "wish to speak a word for Nature" (Thoreau, 1862, p. 225) at Bears Ears also speak back to an ethics of (ecological) care, responsibility, and respond to injustices on the sacred lands.

The literature-as-advocacy canon crafted around a conservation battle to protect Bears Ears deploys a quiet politics_or "gentle anarchy" (cf. Purdy, 2017)—in defending its biography of place. Gentleness and acting gently in literary environmental activism, then, might be understood as recognizing the capacity for literature to tell of, and importantly call for, a more careful/care-full and responsible engagement with the more-than-human (after Finn and Jeffries, this volume). But acting gently can also be at turns subversive, unsettling, uncomfortable, persistent (Maynard, 2018; Pottinger, 2017), and this paper is interested in this troubling of gentleness and acting gently for ecological and political reform, and how this might play out in modifying actions at Bears Ears.

This exposition of a gentle literary activism at Bears Ears is rooted in and informed by geographical scholarship on quiet politics (Askins, 2014, 2015) and quiet activisms (Pottinger, 2017; also Maynard, 2018). For Pottinger (2017, p. 217), quiet activism refers to "a form of engagement that emphasises embodied, practical, tactile and creative ways of acting, resisting, reworking and subverting." As this paper demonstrates, a gentle literary activism is one way of 
enacting a quiet politics. The literary activism at Bears Ears offers a creative, yet subversive, response to threats to Utah's public lands.

The quiet politics in/of activism and resistance has long been of interest to geographers, especially its refocusing, rescaling of activism to everyday, intimate, affective entanglements (see e.g. Horton and Kraftl, 2009, on "implicit activisms," also Askins, 2014, 2015; Maynard, 2018; Pottinger, 2017). At Bears Ears, this rescaling plays out through the literary imaginary, as writing becomes a political act detailing a commitment, investment, and intimacy with Bears Ears country. Pain and Staeheli's (2014) work on intimacy-geopolitics is particularly useful for understanding the Bears Ears context. While this paper on Bears Ears aligns more closely with cultural geography than feminist geopolitics, Pain and Staeheli's (2014) focus on scaleparticularly a destabilizing, upending of a spatial hierarchy, with intimate, social, and local relations stretching across time and space, to punctuate wider discourses and structures, as well as behaviors - can be transposed onto the conservation campaign in the Utah desert.

As desert writers converge to defend the buttes and mesas of Bears Ears, political action is redrawn around everyday encounter and experience-it is political engagement at the social, local scale. But while this quiet activism is personal, intimate, embodied, reflective, and engages with local, state politics-within southern Utah-it also extends into and infiltrates federal politics and national political dialogue. There is, as Pain and Staeheli (2014, p. 346) argue, "the potential for feelings and inter-personal relationships to effect political change at other scales. Here intimacy-geopolitics is used effectively to articulate the inseparability of politics from emotional geographies." Revealed through the Bears Ears controversy is an inter-scaling of the political-personal. Although closely tied to Bears Ears, this literature travels across multiple sites and scales. Through a literary defense of the Bears Ears desertscape, writers also interrogate our ethical responsibilities to care for public lands (on the geographies of ethics, care, and responsibility, see Lawson, 2007; Massey, 2004; McEwan and Goodman, 2010). An intimacy with the desert is reworked into activism.

If the Bears Ears and Grand Staircase-Escalante national monuments are now united in their dual dismantling, they were earlier tied by a shared history of literary advocacy. This paper begins by unpacking the template for literature-as-advocacy that emerged with Grand StaircaseEscalante in the mid-1990s, before turning to the politically-charged situation that unfolded at Bears Ears in the mid-2010s. In particular, this paper traces the quiet politics bound up in literary commentary supporting a Bears Ears national monument, and how, across a change in administrations, and political ideologies, it has evolved from a rhetoric of promise and hope to one of defense and riposte. 


\section{BEFORE BEARS EARS: A LITERARY 'ACT OF FAITH' IN DEFENSE OF UTAH WILDERNESS}

The literary advocacy that mobilized at Bears Ears has its origins in the story of another Utah national monument two decades earlier-Grand Staircase-Escalante. And that story began in an unlikely place - the Utah Public Lands Management Act of 1995. Utah writer and activist Terry Tempest Williams spoke out against this anti-wilderness bill, testifying on conservation panels before hearings in both Utah and Washington, D.C., but was dismayed by the undisguised indifference and boredom on the part of committee members to environmental issues (Williams in Sumner, 2006; Williams, 2012). Upon returning to Utah from Washington, D.C., Williams began a collaboration with fellow Utah environmental writer-activist Stephen Trimble to compile a small chapbook featuring Western writers that celebrated Utah wilderness (on nature writing and environmental politics, see Payne, 1996; Philippon, 2004).

With the essays and poems submitted following a plea to more than two dozen writers in early August 1995 asking, "Dear Friends: [...] We need your help," and continuing, "We write to ask you, along with the writers above, to donate a short piece for a chapbook we will design and bind with care and place on the desk of every congressperson and senator by the end of September" (Trimble \& Williams, 1996, pp. 94-95), the pair compiled Testimony: Writers of the West Speak on Behalf of Utah Wilderness (Trimble \& Williams, 1996; Williams, 2012; cf. Trimble, 2017). Signatures from each contributor added "solidarity and depth $[\ldots]$ power and presence" (Williams qtd. in Sumner, 2006, p. 106, Williams, 2012, p. 154) to the literary project. In late September, a press conference in Washington, D.C. launched the chapbook into the halls of Congress.

In late March the following year, when the Utah anti-wilderness bill arrived on the floor of the U.S. Senate, it triggered a filibuster, during which time Trimble and Williams's (1996) chapbook was read aloud on the Senate floor (Williams in Sumner, 2006; Williams, 2012). And elsewhere, after establishing Utah's 1.9-million-acre Grand Staircase-Escalante National Monument in September 1996, President Clinton declared of the chapbook: "This little book made a difference" (qtd. in Williams, 2012, p. 157). Trimble and Williams (1996, p. 7) closed their editorial essay, "An Act of Faith," with the affirmation, "We believe in the power of story to bypass political rhetoric and pierce the heart. We live in the geography of hope." The eventual dismissal of the 1995 anti-wilderness bill, and the national monument designation, might be a fulfilment of that hope. 
Trimble and Williams's (1996) chapbook is not the first time conservation voices have come together on a collaborative, collective literary project to "speak a word for" Utah's public lands (cf. Porter, 1963; Stegner, 1955). But what sets Trimble and Williams's (1996) book apart is an ecological and political legacy that extends beyond state lines. It has inspired other chapbooks and anthologies speaking out in defense of public lands from Alaska to Minnesota and Florida, from Montana to New Mexico and California (Williams in Sumner, 2006). But the legacy of Trimble and Williams's (1996) Testimony would return to Utah, as the battle to secure another Utah national monument-Bears Ears—reached its zenith.

\section{THE GENTLE ENVIRONMENTAL ACTIVISM BRUIN IN SOUTHEAST UTAH}

\subsection{In anticipation of a Bears Ears national monument}

Lobbying by Native Nations to secure the protection of the sacred, ancestral lands of the Bears Ears in southeastern Utah began almost eight decades ago. In mid-2015, the Bears Ears InterTribal Coalition, a group of five sovereign tribal nations with strong ties to Bears Ears-Hopi, Navajo, Uintah and Ouray Ute, Ute Mountain Ute, and Zuni-submitted a proposal for Bears Ears National Monument to the Obama administration.

But the Obama administration's recommendation encouraged the BEITC to pursue a legislative resolution in Congress, before the president used his authority under the Antiquities Act to designate a national monument (Trimble, 2017). For a number of months, the BEITC contributed to Utah's Public Lands Initiative, which included management plans for the Bears Ears region. But the PLI's "grand bargain" vibrated against Native American land management priorities, and before the end of the year the BEITC had reluctantly withdrawn from the PLI and resumed its national monument campaign.

It is against this political backdrop of the PLI pitched against a bid for national monument status that another literature-as-advocacy campaign emerged. Utah's community of writers and activists threw its support behind the BEITC bid for a Bears Ears national monument. With Stephen Trimble at the helm once more, and following the model of Trimble and Williams (1996) in both spirit and name, Red Rock Testimony: Three Generations of Writers Speak on Behalf of Utah's Public Lands, a chapbook of essays and poems celebrating Bears Ears, was produced and distributed to Congress (and selected federal agencies) in June 2016 (the title later changed to Red Rock Stories_-see Trimble, 2017). Introducing the collection, Trimble (2017, p. 6) argues the essays, "address historical context, natural history and archaeology, energy threats, faith, and politics. Together, they offer a nuanced case for restraint and respect in this incomparable redrock landscape." Contributors include activists, scientists, historians, former 
elected officials, and Native American tribal leaders-some of whom are earlier contributors to Trimble and Williams's (1996) chapbook.

Torrey House Press, the Utah-based independent publisher behind the Bears Ears chapbook, launched a Kickstarter campaign in late June 2016 to fund the publication of another anthology of Bears Ears writings, dedicated to-and amplifying-Native voices. Edited by Navajo/Yankton Dakota Sioux writer Jacqueline Keeler, Edge of Morning: Native Voices Speak for the Bears Ears tells of the "fight for the land and our culture" (Keeler, 2017, p. 6), and includes interviews with organizers of the BEITC, alongside essays from activists, scholars, and indigenous leaders.

This literary advocacy from both conservation and Native communities was absorbed into a nationwide environmental movement calling for the creation of the national monumentthat was realized with just 23 days left of the Obama presidency. But less than two months after the designation, the future of Bears Ears National Monument would be cast in doubt-and southern Utah would become the nexus of a nationwide debate on the legacy of the Antiquities Act.

\subsection{In the aftermath of the remaking of Bears Ears and Grand Staircase-Escalante}

Before the end of President Trump's first year in office, the boundaries of Bears Ears and Grand Staircase-Escalante would be unrecognizable. What began with the filing of three resolutions in the Utah Senate to yoke the two monuments, progressed to a presidential executive order requesting a review of two decades of national monument designations, before culminating in the twin presidential proclamations that shrank Bears Ears by $85 \%$ and Grand StaircaseEscalante by almost $50 \%$.

Anthologies such as Trimble (2017) and Keeler (2017) capture the impassioned and fervent debate that accompanied and defined the fight to protect Bears Ears. Within these anthologies, contributors are embracing the meeting between gentleness and anarchismbalancing a gentle, creative, performative response or intervention with political protest-to speak out on the defense of public lands. Yet these volumes are nevertheless static, for they tell of and are set against the political context in the run up to (and immediately following) the designation of Bears Ears National Monument. But these texts have been politicized anew in response to the actions of the Trump administration-both as elegies, eulogies to what was lost in the severe modifications to the national monument boundaries, and as a rallying cry, or callto-arms. And in the aftermath of the modifications to the Bears Ears and Grand Staircase-

Escalante national monuments, two new companion volumes have joined this expanding 
canon-an essay collection that knits together the frictions and tensions between Native and Mormon cultures, and local, state, and federal political interests pre- and post-designation (Robinson, 2018), and a photographic journey through Bears Ears country, and the lands now largely omitted from the revised national monument (Strom, 2018).

The gentle anarchies (Purdy, 2017) or quiet activisms (Askins, 2014, 2015; Maynard, 2018; Pottinger, 2017) presented through these anthologies encourage a careful/care-full celebration of the more-than-human — of past and present (and future) Bears Ears and Grand Staircase-Escalante lands, and public lands across Utah and the U.S. They also offer a tonic-a platform for gentle resistance, subversion-to the ecological violence incurred by the Trump administration's decision to open up former Bears Ears and Grand Staircase-Escalante lands to oil and gas exploration.

\section{CONCLUSION}

Set amidst the conservation fight still raging in southeastern Utah to shore up the Bears Ears National Monument designation, this paper offers a provocation on gentleness and acting gently in literary activism. Cutting across the Bears Ears literary canon is an ethic of (ecological) care and responsibility (Lawson, 2007; Massey, 2004; McEwan and Goodman, 2010), as desert writers come together and stand up for the national monument designation. For geographers interested in gentle epistemologies and methodologies, literary activism as enacted at Bears Ears illustrates how writing can mold and inform political rhetoric, dialogue, and debate-literature becomes a gentle intervention, revealing a quiet politics of dissent and protest.

The quiet politics of literary activism has become an integral part of the arsenal of environmental activists working to defend Utah's Bears Ears National Monument. Through chapbooks and anthologies, the canyons and mesas, stories and histories, of Bears Ears country are curated and archived-but also weaponized in defense of public lands. These volumes also show how environmental activism and advocacy at Bears Ears has weathered, and responded to, political maneuvering to roll back public lands protections. If early entries in a Bears Ears conservation canon are full of hope and celebration, many later entries are defined by their guarded, defensive, almost elegiac tone. And all the while, the battle for Bears Ears National Monument persists. Although now, perhaps, it is characterized by a disquieting politics. And long may it last.

\section{REFERENCES}


Askins, K. (2014) A quiet politics of being together: Miriam and Rose. Area 46, 353-354. https://doi.org/10.1111/area.12138_5

Askins, K. (2015). Being Together: Everyday Geographies and the Quiet Politics of Belonging. ACME: An International E-Journal for Critical Geographies 14, 470-478.

Horton, J. \& Kraftl, P. (2009). Small acts, kind words, and "not too much fuss:" Implicit activisms. Emotion, Space, and Society 2, 14-23. https://doi.org/10.1016/j.emospa.2009.05.003

Keeler, J. (Ed.) (2017). Edge of Morning: Native Voices Speak for the Bears Ears. Salt Lake City and Torrey, UT: Torrey House Press.

Lawson, V. (2007). Geographies of Care and Responsibility. Annals of the Association of American Geographers 97, 1-11. https://doi.org/10.1111/j.1467-8306.2007.00520.x

Massey, D. (2004). Geographies of Responsibility. Geografiska Annaler B, 86, 5-18. DOI: https://doi.org/10.1111/j.0435-3684.2004.00150.x

Maynard, N. (2018) Activism across the lifecourse: Circumstantial, dormant and embedded activisms. Area, 50, 205-212. https://doi.org/10.1111/area.12349

McEwan, C. \& Goodman, M.K. (2010). Place Geography and the Ethics of Care: Introductory Remarks on the Geographies of Ethics, Responsibility, and Care. Ethics, Place \& Environment 13, 103-112. https://doi.org/10.1080/13668791003778602

Pain, R. and Staeheli, L. (2014) Introduction: intimacy-geopolitics and violence. Area 46, $344-$ 347. https://doi.org/10.1111/area.12138

Payne, D.G. (1996). Voices in the Wilderness: American Nature Writing and Environmental Politics. Hanover, NH \& London: University Press of New England.

Philippon, D.J. (2004). Conserving Words: How American Nature Writers Shaped the Environmental Movement. Athens, GA \& London: University of Georgia Press.

Porter, E. (1963). The Place No One Knew: Glen Canyon on the Colorado. San Francisco, CA: Sierra Club.

Pottinger, L. (2017) Planting the seeds of a quiet activism. Area 49, 215-222. https://doi.org/10.1111/area.12318

Purdy, J. (2017). The Gentle Anarchy of the Park Ranger. The Atlantic, https://www.theatlantic. com/science/archive/2017/01/lore-of-the-park-ranger/514832. Accessed 15 February 2019.

Robinson, R.M. (2018). Voices from Bears Ears: Seeking Common Ground on Sacred Land. Tucson, AZ: University of Arizona Press. 
Stegner, W. (Ed.) (1955). This Is Dinosaur: Echo Park Country and Its Magic Rivers. New York, NY: Alfred A. Knopf.

Strom, S.E. (2018). Bears Ears: Views from a Sacred Land. Staunton, VA: George F. Thompson Publishing, LLC.

Sumner, D.T. (2006). Testimony, Refuge, and the Sense of Place: A Conversation with Terry Tempest Williams. In M. Austin (Ed.), A Voice in the Wilderness: Conversations with Terry Tempest Williams (pp. 100-114). Logan, UT: Utah State University Press.

Thoreau, H.D. (1862). Walking. In E.H. Witherell (Ed.) (2001), Thoreau: Collected Essays and Poems (pp. 225-255). Washington, D.C.: Library of America.

Trimble, S. (Ed.) (2017). Red Rock Stories: Three Generations of Writers Speak on Behalf of Utab's Public Lands. Salt Lake City \& Torrey, UT: Torrey House Press.

Trimble, S. \& Williams, T.T. (Eds.) (1996). Testimony: Writers of the West Speak on Behalf of Utah Wilderness. Minneapolis, MN: Milkweed Editions.

Williams, T.T. (2012). When Women Were Birds: Fifty-Four Variations on Voice. New York, NY: Picador. 